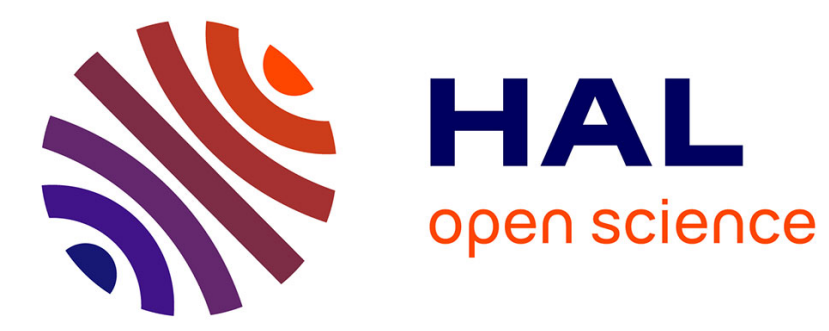

\title{
26Al measurement with a cyclotron
}

G.M. Raisbeck, F. Yiou, C. Stephan

\section{To cite this version:}

G.M. Raisbeck, F. Yiou, C. Stephan. 26Al measurement with a cyclotron. Journal de Physique Lettres, 1979, 40 (12), pp.241-244. 10.1051/jphyslet:019790040012024100 . jpa-00231616

\section{HAL Id: jpa-00231616 https://hal.science/jpa-00231616}

Submitted on 1 Jan 1979

HAL is a multi-disciplinary open access archive for the deposit and dissemination of scientific research documents, whether they are published or not. The documents may come from teaching and research institutions in France or abroad, or from public or private research centers.
L'archive ouverte pluridisciplinaire HAL, est destinée au dépôt et à la diffusion de documents scientifiques de niveau recherche, publiés ou non, émanant des établissements d'enseignement et de recherche français ou étrangers, des laboratoires publics ou privés. 


\title{
${ }^{26} \mathrm{Al}$ measurement with a cyclotron
}

\author{
G. M. Raisbeck, F. Yiou \\ Laboratoire René Bernas du Centre de Spectrométrie Nucléaire et de Spectrométrie de Masse, \\ 91406 Orsay, France \\ and C. Stephan
}

Institut de Physique Nucléaire, 91406 Orsay, France

(Reçu le 5 mars 1979, accepté le 23 avril 1979)

\begin{abstract}
Résumé. - Nous avons utilisé l'accélérateur ALICE pour le comptage direct de très faibles quantités ( $\sim 5 \times 10^{9}$ atomes) de l'isotope radioactif ${ }^{26} \mathrm{Al}$ (période $7,3 \times 10^{5}$ ans). Nous discutons comment la mesure de ce nucléide dans les sédiments marins en liaison avec des mesures similaires de ${ }^{10} \mathrm{Be}$ (période $1,5 \times 10^{6}$ ans) peut être utilisée comme technique de datation absolue. La méthode utilisée pour éviter l'interférence de l'isobare stable ${ }^{26} \mathrm{Mg}$ est applicable à un certain nombre d'autres isobares de nucléide de période longue, permettant ainsi d'élargir le domaine d'application de la technique d'accélérateur.
\end{abstract}

Abstract. - We have used the accelerator facility ALICE to count directly small quantities ( $5 \times 10^{9}$ atoms) of the isotope ${ }^{26} \mathrm{Al}$ (half-life $=7.3 \times 10^{5}$ years). We discuss how measurement of this nuclide in marine sediments, in conjunction with similar measurements of ${ }^{10} \mathrm{Be}$ (half-life $=1.5 \times 10^{6}$ years), can be used as an absolute dating technique. The method used here to avoid interference from the isobar ${ }^{26} \mathrm{Mg}$ is applicable to a number of other isobars of interesting long lived nuclides, thus expanding the potential application of the accelerator technique.

The last two years have seen a great deal of activity in the measurement of radionuclides using nuclear accelerators. Quantitative results have been published to date for the isotopes ${ }^{3} \mathrm{H}[1],{ }^{14} \mathrm{C}[2,3],{ }^{10} \mathrm{Be}$ [4] and ${ }^{36} \mathrm{Cl}$ [5]. We report here the application of this technique to the determination of ${ }^{26} \mathrm{Al}$ (half-life $=730000$ years). We chose this isotope for two reasons : i) its interest (in conjunction with ${ }^{10} \mathrm{Be}$ ) for dating marine sediments, ii) because it belongs to a class of cosmogenic nuclides (including ${ }^{36} \mathrm{Cl},{ }^{41} \mathrm{Ca},{ }^{53} \mathrm{Mn},{ }^{59} \mathrm{Ni}$ ) which have a lower atomic number stable isobar, thereby posing special problems for the accelerator technique. These two aspects are discussed briefly below.

We have discussed elsewhere [4] the use of ${ }^{10} \mathrm{Be}$ for investigating various geophysical and astrophysical parameters which influence its cosmogenic production rate. The use of this isotope for dating poses two problems. (i) Because ${ }^{10} \mathrm{Be}$ and the stable isotope ${ }^{9} \mathrm{Be}$ are not mixed in the atmosphere, they do not necessarily have a constant or known initial ratio in geophysical reservoirs. (ii) Because of the ${ }^{10} \mathrm{Be}$ production variations mentioned above, even a geophysical reservoir with a constant ${ }^{9} \mathrm{Be}$ input will not have a constant initial ${ }^{10} \mathrm{Be} /{ }^{9} \mathrm{Be}$ ratio. These pro- blems have led Lal [6] to suggest the simultaneous use of ${ }^{10} \mathrm{Be}$ (half-life $=1.5 \times 10^{6}$ years [7]) and ${ }^{26} \mathrm{Al}$ (half-life $=7.3 \times 10^{5}$ years) for dating in marine sediments. The reasoning is that, since these two isotopes are expected to have similar chemical behaviour in sea water, they will be deposited in sediments together, with a ratio corresponding to their production rates. In addition, since they are both formed in the atmosphere by similar high energy spallation reactions $\left({ }^{10} \mathrm{Be}\right.$ from ${ }^{14} \mathrm{~N}$ and ${ }^{16} \mathrm{O},{ }^{26} \mathrm{Al}$ from $\left.{ }^{40} \mathrm{Ar}\right)$, variations in the production rate will tend to cancel out. Thus the ratio ${ }^{26} \mathrm{Al} /{ }^{10} \mathrm{Be}$ in marine sediments will decay with an effective half-life of 1.42 million years, independent of fluctuations in production or deposition rates. When this suggestion was originally made [6], it was believed that a large influx of ${ }^{26} \mathrm{Al}$ in cosmic dust might complicate this simple relationship. The most recent analysis of this question, however, indicates that atmospheric production of ${ }^{26} \mathrm{Al}$ does indeed dominate other sources [8].

When discussing the possibility of measuring ${ }^{26} \mathrm{Al}$ with a cyclotron, Muller [1] noted that ${ }^{26} \mathrm{Mg}$ was likely to give severe interference, and could not be preferentially absorbed, as is the case for the systems ${ }^{14} \mathrm{~N}-{ }^{14} \mathrm{C}$ and ${ }^{10} \mathrm{~B}-{ }^{10} \mathrm{Be}$. A similar problem holds for 
several other interesting isotopes $\left({ }^{36} \mathrm{Cl},{ }^{41} \mathrm{Ca},{ }^{53} \mathrm{Mn}\right.$, ${ }^{59} \mathrm{Ni}$ ). In fact, although it has a natural abundance of only $\sim 10^{-4}$, interference from ${ }^{36} \mathrm{~S}$ was the limiting factor in recent experiments on naturally occurring ${ }^{36} \mathrm{Cl}$ using a tandem Van de Graaff accelerator [5]. It occurred to us that if the isotope in question could be accelerated to an energy where it could be fully stripped, then the necessary separation could be effected by magnetic analysis. The desire to test this possibility provided the second motivation for this work.

The energy necessary for complete stripping of ${ }^{26} \mathrm{Al}$ is not available at the Grenoble cyclotron, where we have carried out our ${ }^{10} \mathrm{Be}$ work. It was therefore decided to use the combination linear accelerator + cyclotron (ALICE) at Orsay for this project. It should be noted that because it uses external injection, ALICE has several of the same advantages discussed with regard to the external ion source at the Grenoble cyclotron [4]; namely the possibility of changing samples without any changes in the cyclotron parameters, and the ability to make frequent (or even continuous) current measurements of the stable isotope, again with no changes in the accelerator parameters.

A schematic diagram of the experimental setup is shown in figure 1 . The ${ }^{26} \mathrm{Al}^{+3}$ ions were accelerated to $1.05 \mathrm{MeV} / \mathrm{n}$ in the linear accelerator and, after being stripped to ${ }^{26} \mathrm{Al}^{+9}$, accelerated to $7.7 \mathrm{MeV} / \mathrm{n}$ in the cyclotron. The entire accelerator system (linear accelerator + cyclotron + associated beam lines) was first tuned using ${ }^{26} \mathrm{Mg}$ from an oven source. Thereafter, all parameters were left fixed and the $\mathrm{Al}$ sample inserted in the sputtering ion source.
The samples for these experiments consisted of pieces of Al foil which had been irradiated with $600 \mathrm{MeV}$ protons several years ago. The ${ }^{26} \mathrm{Al}$ content was calculated by measuring the ${ }^{22} \mathrm{Na}$ activity, and using the known cross section ratio for the production of ${ }^{22} \mathrm{Na}$ and ${ }^{26} \mathrm{Al}$ [9]. The concentration ratio ${ }^{26} \mathrm{Al} / \mathrm{Al}$ ranged from $10^{-8}$ to $10^{-11}$. The $\mathrm{Al}(10-50 \mathrm{mg})$ was fixed to the sputtering dynode of the ion source by means of a $\mathrm{Cu}$ cover having a $5 \mathrm{~mm}$ diameter hole, through which the Al was exposed. Despite the limited surface, off-line tests showed that this system could give more than $100 \mu \mathrm{A}$ of $\mathrm{Al}^{+3}$ for several hours. During the actual experiment, currents of $30-40 \mu \mathrm{A}$ were used. This current could be continually monitored by a Faraday cup at the entrance to the linear accelerator. Samples of sintered $\mathrm{Al}_{2} \mathrm{O}_{3}$ were also tried, but gave currents an order of magnitude lower.

After extraction from the cyclotron, the ${ }^{26} \mathrm{Al}$ (and contaminating ${ }^{26} \mathrm{Mg}$ ) were passed through a thin foil $\left(100 \mu \mathrm{g} / \mathrm{cm}^{2} \mathrm{C}\right.$ or $\left.600 \mu \mathrm{g} / \mathrm{cm}^{2} \mathrm{Au}\right)$ where they could be stripped to charges +13 and +12 respectively, and separated in a $120^{\circ}$ magnetic analyser. The detecting element consisted of a pair of silicon surface barrier detectors (thickness $\Delta E=17 \mu \mathrm{m} ; E=200 \mu \mathrm{m}$ ) connected through standard electronics to a two dimensional $(64 \times 128$ channels) multichannel analyser. The ${ }^{26} \mathrm{Mg}$ (which ranged in intensities from $10^{4}$ to $10^{6}$ particles/s) was used to calibrate the magnetic analyser and to optimize the position of the $\mathrm{d} E / \mathrm{d} x-E$ telescope. By varying the cyclotron frequency while monitoring the ${ }^{26} \mathrm{Mg}$, we were able to establish that the resolution of the cyclotron was $\gtrsim 10^{-3}$ (significantly larger than with the Grenoble cyclotron [4]). Therefore, there was no need to vary the cyclotron

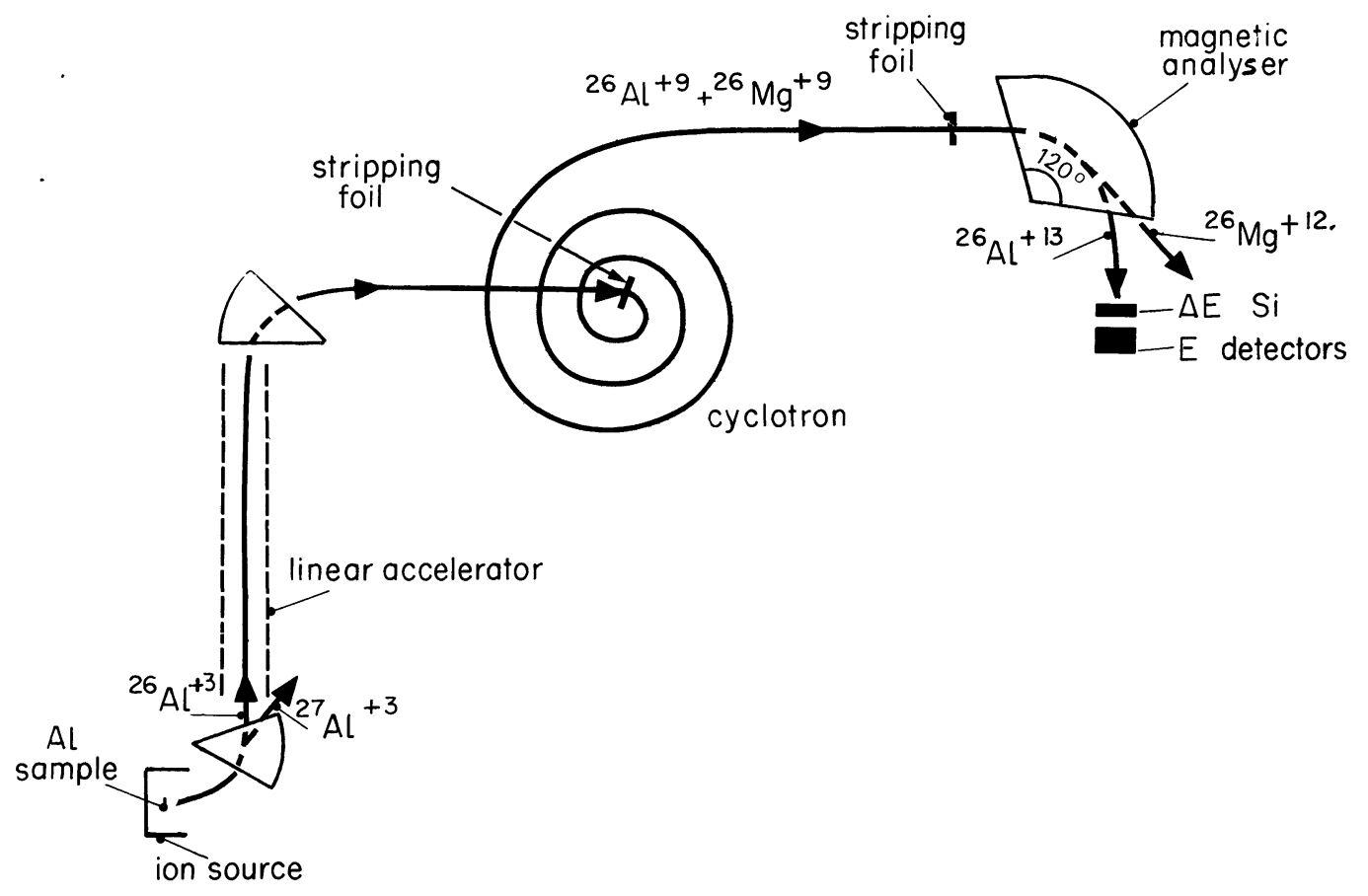

Fig. 1. - Schematic diagram of experimental layout. 
parameters when changing between ${ }^{26} \mathrm{Mg}$ and ${ }^{26} \mathrm{Al}$, which differ in mass by $\sim 1.6 \times 10^{-4}$. Once the analyser had been calibrated for ${ }^{26} \mathrm{Mg}^{+12}$, it could be very accurately adjusted for ${ }^{26} \mathrm{Al}^{+13}$ by means of a nuclear magnetic resonance probe.

In figure 2 we show an example of a $\Delta E \times E$ spectra obtained for events recorded with the analyser set to accept ${ }^{26} \mathrm{Al}$. In addition to the ${ }^{26} \mathrm{Al}$, there are peaks corresponding to the calculated positions of ${ }^{26} \mathrm{Mg}^{+12}$ and ${ }^{26} \mathrm{Mg}^{+11}$ having the same magnetic rigidity as the ${ }^{26} \mathrm{Al}$. These probably represent ${ }^{26} \mathrm{Mg}$ ions scattered in the beam line. It is evident however that these events are well separated from the ${ }^{26} \mathrm{Al}$ peak.

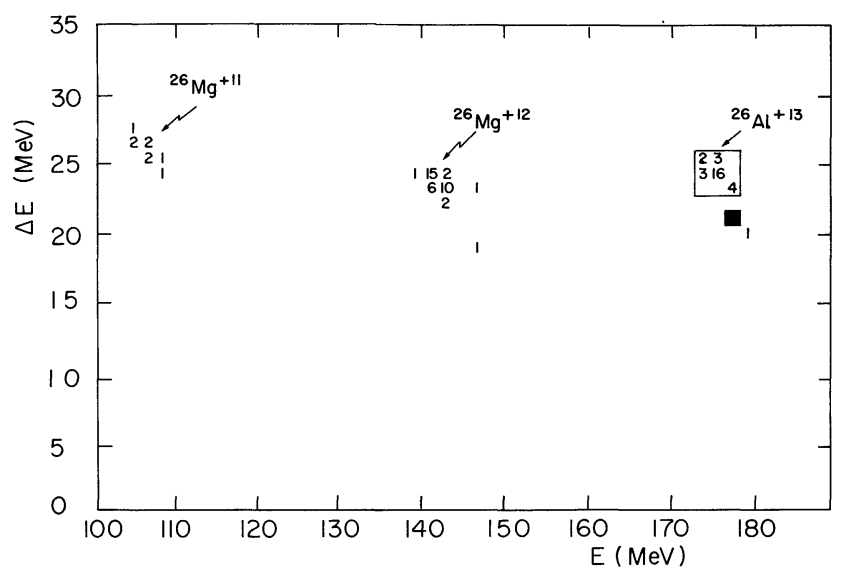

Fig. 2. - Portion of a $\Delta E-E$ spectra for 10 minutes run on a sample having ${ }^{26} \mathrm{Al} / \mathrm{Al}=10^{-11}$. Figures represent the number of events in a given channel. Events in square correspond to ${ }^{26} \mathrm{Al}$. The solid square shows the position of the observed peak when the analyser was set to the magnetic rigidity of $200 \mathrm{MeV}^{26} \mathrm{Mg}^{+12}$

The number of ${ }^{26} \mathrm{Al}$ atoms in our least concentrated sample $\left({ }^{26} \mathrm{Al} / \mathrm{Al}=10^{-11}\right)$ was $\sim 5 \times 10^{9}$. A series of four ten-minute measurements on this sample gave a count rate of $2.9 \pm 0.5 \mathrm{cpm}$. The standard deviation is consistent with statistical fluctuations in the number of ${ }^{26} \mathrm{Al}$ atoms counted. A run with pure ${ }^{27} \mathrm{Al}$ gave no counts in 10 minutes, corresponding to a background of ${ }^{26} \mathrm{Al} /{ }^{27} \mathrm{Al}<10^{-12}$. Based on these results, we thus conservatively estimate that samples containing $10^{9}$ atoms of ${ }^{26} \mathrm{Al}$ could be measured under the above conditions. This corresponds to the quantity of ${ }^{26} \mathrm{Al}$ in $\sim 40 \mathrm{~g}$ of fresh ocean sediment [8]. Allowing for improvements in the ion source conditions and accelerator transmission which are known to be available, we believe that the above sensitivity can be improved by at least an order of magnitude.

In addition to interference by ${ }^{26} \mathrm{Mg}$, a second problem for the accelerator determination of cosmogenic ${ }^{26} \mathrm{Al}$, as noted by Muller [1], is the large natural abundance of ${ }^{27} \mathrm{Al}$. Indeed the typical ratio of ${ }^{26} \mathrm{Al} /{ }^{27} \mathrm{Al}$ in fresh marine sediments is $\sim 10^{-14}$, and thus would seem at first glance, to exclude measurements with the $\mathrm{Al}$ beam currents presently available at ALICE. There are, however, two possible approaches that might still make such measurements possible. The first is a preenrichment step with an isotope separator, which we have mentioned elsewhere [10] in connection with ${ }^{41} \mathrm{Ca}$. In fact, separation factors of $10^{4}$, with $10 \%$ recuperation seem quite realistic (R. Meunier, private communication). A second possibility would take advantage of the fact that most of the ${ }^{27} \mathrm{Al}$ in marine sediments is detritic, and therefore has not passed the ocean in solution. In fact, Yokoyama et al. [11], have estimated, based on the ${ }^{26} \mathrm{Al} / \mathrm{Al}$ ratio in a $\mathrm{Mn}$ nodule, that the authigenic (i.e. soluble) ${ }^{26} \mathrm{Al} /{ }^{27} \mathrm{Al}$ ratio is $\sim 10^{-11}$. If these authigenic phases could be isolated from sediments, then a direct measurement with the technique outlined above appears feasible. In addition, of course, there are a number of other environments (polar ice, meteorites and lunar samples, manganese nodules) where the ${ }^{26} \mathrm{Al} / \mathrm{Al}$ ratio is much larger than in marine sediments. For such samples the most important parameter is the minimum number of ${ }^{26} \mathrm{Al}$ atoms which can be detected. A sensitivity of $10^{9}$ atoms (corresponding to $\sim 2$ disintegrations per day) is already an order of magnitude better than the most sophisticated low level $\gamma$ counters have achieved $[8,12]$.

Finally, returning to the second objective of this work, we feel that the most important result of this experiment is to demonstrate that accelerator detection of nuclides having lower atomic number stable isobars is feasible without extensive chemical purification steps. This then potentially opens up this technique to an even wider range of isotopes than has been studied to date.

Acknowledgments. - We would like to thank the entire operating and support staff of ALICE, and in particular L. Martial, A. Richomme, J. Depauw and A. Le Goff for their assistance in this somewhat unusual use of the accelerator. 


\section{References}

[1] Muller, R. A., Science 196 (1977) 489.

[2] Bennet, C. L., Beukens, R. P., Clover, M. R., Gove, H. E., Liebert, R. B., Litherland, A. E., Purser, K. H. and SondheIM, W. E., Science 198 (1977) 508 ; and

BENNET, C. L. et al., Science 201 (1978) 345.

[3] Muller, R. A., Stephenson, E. J., Mast, T. S., Science 201 (1978) 348.

[4] Raisbeck, G. M., Yiou, F., Fruneau, M. and Loiseaux, J. M., Science 202 (1978) 215 ;

RAISBECK, G. M. et al., Nature 275 (1978) 731 ; and

RAISBECK, G. M. et al., Earth Planet Sci. Lett. (in press).

[5] Elmore, D., Fulton, B. R., Clover, M. R., Marsden, J. R., Gove, H. E., Naylor, H., Purser, K. H., Kilius, L. R., BeUkens, R. P. and Litherland, A. E., Nature 277 (1979) 22.
[6] LAL, D., J. Oceanogr. Soc. Japan 20th Anniv. (1962) 600

[7] Yiou, F. and RaisbeCK, G. M., Phys. Rev. Lett. 29 (1972) 372.

[8] Reyss, J. L., Yokoyama, Y. and Tanaka, S., Science 193 (1976) 1119

[9] Raisbeck, G. M., Menninga, C., Brodzinski, R. and WoGman, N., Proc. 15th Int. Cosmic Ray Conf., Plovdiv, Bulgaria 2 (1977) 203.

[10] RaisbeCK, G. M. and Yiou, F., Nature 277 (1979) 42.

[11] Yokoyama, Y., Guichard, F., Reyss, J. L. and NguYen, Hun Van, Science 201 (1978) 1016.

[12] Wogman, N. A. and Brodzinski, R. L., Nucl. Instrum. Methods 109 (1973) 277. 